Conference

Circuit

\title{
Joining forces to promote education and libraries
}

\author{
By Barbara J. Ford
}

\section{The Committee for Education \\ Funding's Legislative Seminar}

$\mathbf{T}$ he Committee for Education Funding (CEF) is a coalition that was founded in 1969 with the goal of achieving adequate federal financial support for our nation's educational system. The coalition is voluntary, nonprofit, and nonpartisan. The American Library Association is a founding and active member of CEF, whose members include educational associations, institutions, agencies, and organizations whose interests range from preschool to postgraduate education in both public and private systems. Mary Costabile, assistant director of the ALA Washington Office, works closely with CEF. Several universities including California State, Georgetown, New York, Princeton, and Michigan are also members.

\section{Providing needed information}

The purpose of CEF is to provide members of the general public, the federal administration, and especially the United States Congress with information that will enable them to better assess the need for funding of federal education programs. The committee takes positions on federal education appropriations issues that represent a consensus of its membership and then communicates those positions to the administration and members of Congress.

$\mathrm{CEF}$ is governed by three elected officers and a 13-member executive committee selected from among the membership. It publishes a timely newsletter, holds meetings of its membership which provide a forum for information exchange and policy discussions, and sponsors seminars on current policy issues led by recognized experts. CEF provides information and assistance to members of Congress and the administration on education funding issues and holds numerous briefing and policy meetings with congressional staff and administration officials during the year. At its annual Congressional Awards Dinner, the committee honors members of Congress for their active support of education programs.

\section{The influence of public opinion}

In September I had the opportunity to attend the CEF Legislative Seminar and Congressional Awards Dinner in Washington, D.C., with members of the ALA Washington Office staff.

The keynote speaker at the seminar was Jack Jennings (Center on National Education Policy) who spoke on "Public Opinion Regarding Federal Education Spending." His main points about the causes of the public's skeptical attitude toward public education were that:

- the major news media are extremely negative about public schools;

- teachers and other educators are losing heart and are starting to turn inward;

- the political far right is criticizing the public schools and this is shaking popular support;

- the public says it wants higher academic achievement from children, but is not willing to change its conduct to realize that end.

Jennings articulately outlined actions that must be taken to deal with these public attitudes:

- the news media must paint a more balanced picture of public education;

- teachers and other educators must explain what they're doing and engage the public in conversations about it;

- civility must be returned to our discourse and the unsubstantiated claims of some far right groups must be rebutted even as their legitimate concerns are addressed; 
- there must be agreement as a nation on what is wanted from the schools and then people must dedicate themselves to attaining those objectives.

According to Jennings, public support for post-secondary education is decreasing and we have lost public appropriations and public support as tuition and fees have gone up. There are cost problems and concerns for those desiring post-secondary education.

The public wants attention and action on these topics of concern. The fight over direct lending for student loans and the growth of the influence of the far right have led some to believe that loans and grants are being used to raise tuition. As recent polls show, education currently has the public's attention and Jennings suggested that higher education must show that it can rein in expenses to continue to get support.

\section{Promoting education}

A panel on "Promoting Education to and through the Media" featured speakers from the American Council on Education (ACE), Education Week, and National Public Radio (NPR). David Merkowitz from ACE reminded us that most newspapers do not have education reporters, including many large ones, so special efforts are needed to get positive press coverage. Coalitions like the Alliance to Save Student Aid have illustrated how that can be done as they have developed press kits and a coherent and consistent strategy to work with students and their parents to raise the issue to national discussion. Mark Pitsch from Education Week talked about the importance of looking at how education affects real people, not just decision-makers, and publicizing what is found.

Claudio Sanchez (NPR's education reporter) outlined some of the important education stories that are not getting covered by the media: African Americans are reaching parity in graduation rates, approximately 40 states do not certify teachers, the march for children on Washington, D.C., affirmative action changes, and others. He said we need to test out ideas locally with the media, especially those that can help close the gap between reality and perceptions. According to Sanchez, once there is local media coverage it is easier to get national coverage.

\section{Politics and awards}

Other panels focused on an update on the FY 1997 budget and appropriations and education in the 1996 presidential campaign. Speakers representing both parties said that both parties support education but there are differing ideas on how that support should be provided and what results are desired.

At the CEF Congressional Awards Dinner, the Award for Outstanding Education Advocacy was presented to secretary of education Richard Riley. The Career Service Award went to senators Mark Hatfield, Nancy Kassebaum, Claiborne Pell, and Paul Simon, and representative Pat Williams. Many of these award winners also support libraries.

\section{A strong and unified coalition}

As the largest coalition of education associations in existence, CEF provides a strong and unified voice in support of federal education funding. Its members include the American Association of Community Colleges, the American Association of State Colleges and Universities, the American Association of University Professors, the Association of American Uni-

\section{both parties support education but there are differing ideas on how that support should be provided and what results are desired.}

versities, the Coalition of Higher Education Assistance Organizations, the National Association of Independent Colleges and Universities, the National Association of Students for Higher Education, and the National Indian Education Association among others. As an active member of the committee, ALA is able to support federal issues relating to all types of educational institutions, including higher education.

There are many allies for ALA and libraries out there and we need to keep reaching out to coalitions such as CEF to get broad support and exposure for libraries. These types of coalitions are especially important for higher education because some of our library funding issues are intertwined with funding for higher education in general. ACRL's support of ALA Goal 2000 and other ALA initiatives has provided resources for working closely with coalitions like CEF. 